\title{
Deconstructing Concealed Gayness Text in The Film Negeri van Oranje: Critical Discourse Analysis
}

\author{
Heri Setiawan \\ University of Jember, Indonesia \\ Email: hry.styawan@gmail.com
}

\begin{abstract}
As one of the most popular creative cultural products, film sometimes speaks beyond what it presents. It is not always produced merely for entertainment purposes, but also to spread a certain ideology and represent a particular culture. Anchored in queer theory, this research looks at the Indonesian film, Negeri Van Oranje, which was chosen purposely to be analyzed using Fairclough's critical discourse analysis model with an aim to deconstruct the concealed gayness text in the film. From the analysis, it was found that the gay scenes in the film try to tell its audience about the positions, feelings, challenges, and rejections that Indonesian gay people experience living amongst heteronormative surroundings. Some new notions about gay people's life in Indonesia are extracted based on the analysis of the gay scenes in the film. The strategy of inserting gay content into a film nationally released in Indonesia is also revealed. The results of the analysis could be used to create a picture of what gay life looks like in Indonesia, a multicultural country that is well-known as the place in which the world's largest Muslim population dwells.
\end{abstract}

Keywords: Negeri Van Oranje film; queer theory; gayness text; gay in Indonesia; Fairclough's critical discourse analysis

\section{INTRODUCTION}

As one of the most popular primary products of the cultural industries, film undoubtedly has a special place in society (Setiawan, 2016: 1). It is one of the manifestations of popular culture that was, is, and will always be enjoyed by many people around the world. According to what is cited from Pranajaya (2000) in Sinthiani (2011:3), it is contended that film is a unique communicative medium with dynamic characteristics and the ability to translate a story directly in the form of audiovisual content. In addition, it is undeniable that films will always carry certain ideologies and representations of a certain culture (Zhang, 2014:2) to be transferred to people. Therefore, it is common to see a film presenting a specific ideology constructed by its directors with the hope that it can penetrate into society and be accepted (Giannetti, 2008: 448-449).

Films are not always as plain as they seem. In some cases, the directors of the films decide to wrap the message in something casual, making it appear to be a common thing in the theater. This is indeed done with some particular purpose, such as to prevent resistance and objection from people so that the film and the ideology planted within can be transmitted to and accepted by the audience successfully.

One of the most sensitive and hate-filled topics to be discussed in Indonesia is homosexuality and any matter related to it. A report by Kwok (2016) claims that it tops communism and illegal drugs as the most condemned topic to enter the public discourse in the country. The concept of heterosexuality, which still has a solid foothold in Indonesia, becomes a great impediment to the freedom of one to present homosexuality in any form of communication, including in film.

This study aims to reveal the concealed messages within a 2015 film called Negeri Van Oranje. 
This film is actually an adaptation of a best-selling novel with the same name released in 2009. The plot of this film surrounds five Indonesian master's degree students' friendship in the Netherlands. In the middle of the story, there are scenes revealing that one of them, Geri, happens to be gay. Eventually, Geri comes out to his friends.

The scenes depicting Geri's coming out and his narration of his feelings associated with being gay will be the foci of this article. The dialogues and scenes will be analyzed using Fairclough's critical discourse analysis model, to dig up the truth and finally delineate what the director of this film wanted to tell about gay life by using the representation of Geri in the film.

There is a myriad of previous research on films in which gayness is the focal topic, such as that by Gythfeldt (2008), Bermudez (2008), Bendel (2013), and Zhang (2014), to name a few. However, something that makes this research different from the aforementioned ones is that it employs Fairclough's critical discourse analysis model amalgamated with queer theory to analyze a film containing gay matter Moreover, the film analyzed in this research is an Indonesian film. Therefore, the results of the analysis of Indonesian gayness would be more profound and more contextual in reflecting what is happening to gay people in Indonesia.

\section{Fairclough's Critical Discourse Analysis}

Fairclough's CDA model, often addressed as a social change model, is influenced by the theory of Mikhail Bakhtin on genre, particularly in the analysis of discourse practice, as well as the theory of Antonio Gramsci's theory of hegemony in the analysis of sociocultural practice (Fairclough, 1995: 2). In his CDA model, there are three stages, namely description, interpretation, and explanation, employed to explore and analyze three elements in a text such as language text (spoken or written), discourse practice (text production and text interpretation), and sociocultural practice (situational, institutional, and societal) (Fairclough, 1989; 1995: 2). These three elements are depicted in Figure 1

\section{Queer Theory}

Queer theory investigates cultural features and discursive actions in societies enforcing heterosexuality as the norm-this is called heteronormativity - and questions the whole concept of sexual identities (Nelson, 1999; Cameron \& Kulick,
Figure 1.

Diagrammatic representation of Fairclough's critical discourse analysis framework, adapted from Fairclough (1995: 98)

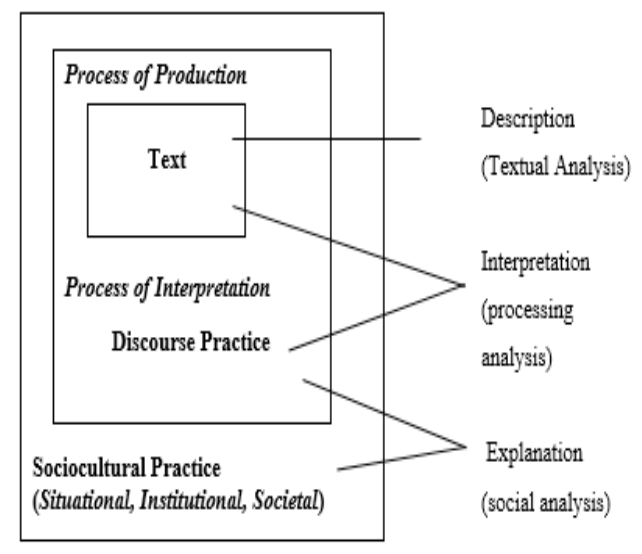

2003; Motschenbacher \& Stegu, 2013) in Rahikainen (2014: 4). This theory more or less questions and deconstructs the notions of fixed genders to which humans have been exposed since a long time ago. In short, queer theory proposes a flexibility, fluidity, and freedom for people to understand, perform, and exercise their gender in whichever way they prefer. This makes this theory appear to be an unorthodox view of discipline (Spargo, 2000).

Queer theory, along with queer criticism, are of paramount importance specifically when analyzing queer films or gay films, since these films are considering human sexuality (Bendel, 2013: 25). The cognizance of these matters will hinder the audience from presupposing and stereotyping the gay films prior to watching them. Therefore, instead of cringing whilst watching the films, they will be directed to enjoy and appreciate their virtues.

\section{Homosexuality in Indonesia and Indonesian Film}

Homosexuality, colloquially known as being gay, is one of three major sexual orientations (the others being heterosexuality and bisexuality) that give people the experience of having love, affection, and romantic feelings - sentimentally or erotically, predominantly or exclusively - towards those with the same sex; e.g. men to men (Sugiarto, 2013: 278; Wedhanti and Fridari, 2014: 363). Although there is no official 
law stating that homosexuality is illegal and can be considered a crime in Indonesia (Yosephine, 2016), rejection from many elements of society who still hold a hetero-patriarchal point of view, the government included, serve as an impediment to gay individuals living with their way of life (Maimunah, 2014:62; Muthmainah, 2016:13). It is not appalling to see this fact since Indonesia is a country with a predominantly Muslim and Christian population. Both religions can be interpreted as conservative, largely disapproving of homosexuality, its practice, and its influences on society (Pew Research Center, 2013; UNDP, USAID, 2014: 9). This rejection of homosexuality is becoming a serious threat for homosexual people in Indonesia because although Indonesia does not enforce Islamic law, the fact that the majority of Indonesians are Muslim makes it unconsciously legal to see this matter using an Islamic point of view (UNDP, USAID, 2014: 23).

That Indonesian culture by and large views gays as belonging to a norm deviant group makes most Indonesian people reticent to accept the existence of gay individuals (Nugroho et al., 2010: 17). Furthermore, it has been found that the gay community is the most hated object in the country, even more so than communism and illegal drugs (Kwok, 2016).

The initial public penetration of homosexuality into the Indonesian film industry occurred in 2002 at the same time as when the Q! Film Festival was held. There were three local films containing homosexual matters, namely Aku, Perempuan dan Lelakimu, Duniaku, Duniamu, dan Dunia Mereka, and Ternyata...! (Maimunah, 2014: 59-60). Although this festival has been held several times, it has done so rather "invisibly" by using the term "queer" instead of "homosexual", so that it is a "queer" film festival as opposed to a "homosexual" one. It can be understood that even though had the courage to hold such a film festival, they were still unsure about revealing their identity publicly.

There are a number of current Indonesian films that explicitly included homosexual matters within in Some of them are Arisan 1 (2003), Coklat Strawberry (2007), Arisan 2 (2010), and Cinta yang Dirahasiakan (2013).

\section{METHODOLOGY}

This research using a qualitative descriptive method anchored in queer theory by employing Fairclough's critical discourse analysis model to analyze the film
Negeri Van Oranje. The film was chosen purposely by taking into account that (1) the film is an Indonesian film, (2) the film is directed by and starring Indonesian people, (3) the film has a gay storyline, (4) the film is relatively new (released in the late 2015), and (4) the film can be easily accessed. Furthermore, this research was conducted to answer questions such as:

1. How are Indonesian gay people and their lives constructed in the film?

2. How do the roles of the film's producers and audience in its production and consumption, respectively, explain a gay person's current condition in Indonesia?

3. How do sociocultural elements affect the production and consumption process of the film?

\section{Negeri Van Oranje}

Negeri Van Oranje is a drama, romance, and adventure film. It was directed by Endri Pelita, in collaboration with the writers of the novel. It was released on December $23^{\text {rd }}, 2015$. The film held the ninth position amongst the ten best-selling Indonesian films in 2015, with an audience of 490,788 and its estimated gross revenue of Rp. 14.4 billion (Film Indonesia, 2015; Riantrisnanto, 2016).

Negeri Van Oranje tells of five Indonesian students undertaking their post-graduate studies in the Netherlands. They are Banjar, Geri, Wicak, Lintang, and Daus. They are united in a group they call AAGABAN. AAGABAN is an abbreviation of Aliansi Amersfoot Gara-Gara Badai di Netherland. Their first meeting in the Netherlands is at Amersfoort when they are trapped in a snow storm in a train station, and they become more intimate as friends afterwards.

However, in the middle of their tight friendship, a problem arises when the four males in the group start to compete to win the heart of Lintang, the lone female. Actually, Lintang has special feelings for Geri, the most charming guy in the group. Fortunately, Geri treats Lintang nicely, just as Lintang expects from him.

Three quarters through the film, when Lintang wants to meet Geri in his apartment, she accidentally sees him and another man about to share a kiss. Lintang is greatly appalled to see that the man whom she adores is gay. Geri then runs after Lintang to explain everything. Initially, Lintang is furious with Geri, for he had never told her and the other friends about his sexual orientation, but after his explains his condition and what he experiences as a gay man, Lintang understands. Geri consequently also comes out to the other friends in AAGABAN. 
The last scene in the film shows Lintang's decision to choose Wicak as her husband.

\section{Instrumentation}

Analysis of the film was conducted by employing Fairclough's model of critical discourse analysis. It consists of three elements to analyze, viz. text, discourse practice, and sociocultural practice (Fairclough, 1995: 97). Text analysis means the text is analyzed linguistically, which includes the vocabulary, grammar, and textual structure (Fairclough, 1996: 111). Those elements were analyzed to answer three things, namely the experiential value (a representation of ideology carried in the text), relational value (construction of the relation between the text producer and the consumers), and expressive value (construction of the identity of the text producers and consumers are presented in the text) (Eriyanto, 2006: 287). However, as Van Dijk (1995) argues that the work of critical discourse analysis is not limited to purely verbal objects, the researcher therefore included the analysis of the representative gay scenes in the film. This will also be considered part of the text analysis stage. Discourse practice analysis is an analysis of the dimensions related to text production, distribution, and the consumption process (Fairclough, 1995: 2; Fauzan: 2013). However, only two of the dimensions will be discussed in this article, viz. the production and the consumption. Information on the production dimension will be derived from the background of the scriptwriters and film director, whilst information on the consumption dimension is acquired from the comments of the audience on YouTube and a number of the film's audience members in the theater. Sociocultural practice analysis is a form of analysis based on the social context outside the production process (Eriyanto, 2006:320-321). In this section, the researcher will present the current social condition in Indonesia towards gay people, particularly in the year when this film was released and in theaters, around 2015-2016.

The use of queer theory is treated by the researcher as the control when analyzing the gay contents of the film. This will help the researcher be cognizant of the other genders rather than only the heterosexual one. Therefore, by being aware of this theory, the researcher will have a better point on the film instead of problematizing the gayness per se.

\section{FINDINGS AND DISCUSSION}

\section{Text Analysis}

Below is a transcript of the conversation between Geri and his friends in AAGABAN while he is coming out.

Lintang:

(1) Kenapa gak loe jujur aja sama gue?

(1) Why did you not just tell me the truth?

Geri:

(2) Jujur kalau gua gay?

(2) To tell you that I am gay?

Lintang:

(3) Gue merasa bego banget tau nggak, Ger! (4)

Selama ini gue pikir loe ke gue...

(3) I feel stupid, you know! (4) I was thinking that you...

Geri:

(5) Gue minta maaf sama lo kalo gue udah buat lo salah nilai perhatian gue selama ini ke lo. (6) Tapi gue sama sekali gak ada maksud apa-apa.

(5) I apologize for that if I have made you misinterpret my attention to you during this time.

(6) But, honestly, I did not have any bad intention by doing that to you.

Lintang:

(7) Terus apa?! (8) Lo yang paling perhatian. (9) Lo yang palingcare. (10) Lo yang paling pengertian sama gue. (11) Buat apa? (12) Buat nutupin diri lo yang sebenarnya?

(7) So what? (8) You are the most caring. (9) You are the most understanding. (10) What are those things for? (11) For what? (12) To hide who you truly are from us?

Geri:

(13) Gue beneran care sama lo. (14) Gue beneran sayang sama lo.

(13) I do care for you. (14) I do love you.

Lintang:

(15) Tapi tanpa lo sadari, lo udah mainin perasaan gue. Geri:

(15) But, unconsciously, you have played my heart.

(16) Gue sama sekali gak ada niat buat mainin perasaan lo, Nan! (17) Sama sekali nggak! (18) I wish gue bisa jujur sama lo. (19) Gue bisa jujur sama diri gue sendiri. (20) Lo pikir ini gampang? (21) Lo tau pandangan orang soal ini kayak gimana. (22) Lo pikir gue seneng ngejalani ini semua? (23) Capek, Nan! (24) Lo harus berpura-pura di depan 
semua orang, karena takut lo gak bisa diterima sama semua orang, sama keluarga lo, sama tementemen lo, bahkan sama sahabat-sahabat loe sendiri! (16) I never have intentions to play your heart, Nan! (17) Never! (18) I wish I could be honest to you. (19) I could be honest to my own self. (20) Do you think this easy? (21) You know how people see this toward this matter. (22) Do you think I am happy with this? (23) I am tired, Nan! (24) You must pretend before all people just because you are afraid of not being accepted by them, by your family, by your friends, even by your best close friends!

Lintang:

(25) Ger, kita sahabat kok. (26) Dan lo gak perlu nutupin apa-apa dari kita.

(25) Ger, we are friends. (26) And you do not need to hide anything from us.

Geri:

(27) Gue minta maaf sama lo semua karena gue baru bisa berterus terang sekarang. (28) Tapi gue jujur, udah... udah lebih lega sih sekarang.

(27) I am sorry because I have just got the courage to tell you all the truth. (28) But, honestly I am relieved now.

Wicak:

(29) Gue aja gak masalah, Bro. (30) Gak ada yang salah yang salah dengan pilihan hidup lo.

(29) I do not have problems with that, Bro. (30)

There is not something wrong with your life choice. Geri:

(31) Thanks.

(31) Thanks.

Banjar:

(32) Ger, gue dukung lo, Bro!

(32) Ger, I support you, Bro!

Daus:

(33) Parah si lo! (34) Tapi ya sudah lah!

(33) Damn, Man! (34) But it is okay! Geri:

(35) Thank you, Us!

(35) Thank you, Us!

Wicak:

(36) Terus minum kita!

(36) Let's drink!

Daus:

(37) Eits, sebentar, sebentar. (38) Eeh... ini buat, penasaran saja sih. (39) Biar clear! (40) Gue penasaran aja. (41) Tapi lo gak bakal ini kan, maksudnya kayak, lo gak punya feeling kan terhadap gue? (42) Nggak maksudnya ini biar clear aja gitu. (43) Abisnya kan kita temen nih, nggak maksudnya, gue khawatir aja nih. (44) Karena kita tu temen gitu dan gue eeh.

(37) Wait a moment. (38) I wonder. (39) I want to make this clear. (40) I wonder. (41)

You will not have a feeling to me, right? (42) Ijust want to make this clear. (43) Well, we are friends, I am just worried. (44) You and I are friends, and I ... Geri:

(45) Soal itu bisa gue jamin dari sekarang

(45) I can guarantee that from now.

Daus:

(46) Oh ya udah kalau gitu.

(46) Oh well... that is good.

\section{Vocabulary Analysis}

In general, the conversation above is mainly about what Geri feels as a gay man. The content of the conversation, particularly between Geri and Lintang, tells of the impediments, challenges, and refusal that Geri experiences in being gay. The words I wish when Geri says "I wish gue bisa jujur sama lo. Gue bisa jujur sama diri gue sendiri," signify that Geri still wishes that he could accept his gayness. This reflects that in fact he rejects his gayness. The word wish in English has a different significance from hope. Wish is seen as more hopeless than hope, meaning that by saying the word wish it is really difficult for Geri to accept his gayness. The idea that Geri rejects his gayness is further supported by the next sentences, " $L o$ pikir gue seneng ngejalani ini semua? Capek, Nan!" The vociferation of "Capek, Nan!" can be regarded as a metaphor signifying that Geri feels hopeless with his gayness. He tries very hard to object to his gayness, but it never becomes productive. This will also relate to the notion that not all gay people are happy and accepting of their gayness. Some of them might say they are proud of being gay, but we could not just generalize this matter. What Geri says in the film is a representation that some gay people reject their gayness and think that being gay is not what they are supposed to be.

The next metaphor is "udah lebih lega sih sekarang". Those words are said after Geri comes out. This can be understood as reflective of the pinnacle moment of a gay person, when they come out. Coming out is seen as the most difficult thing to do. However, once they have the courage to come out, it will ease 
their burden. It is like they are reborn as a new person with a new chapter in their life.

The words, "parah si lo, tapi. Ya sudah lah!" spoken by Daus signify a euphemistic expression of "acceptance" that is preceded by criticism. When Daus says "Parah si lo," it means that Daus actually still cannot accept that Geri is gay and still regards it as something outlandish and deviant. We cannot say that Daus accepts Geri's gayness, but rather merely tolerates it. Acceptance and tolerance are different things. Accepting means that a person agrees and sees that something other people do is right, but tolerating means that a person cannot agree with what other people do but will still respect them in their own way. Acceptance is reflected in the sentences spoken by Wicak and Banjar in reference to Geri's gayness, "Gue aja gak masalah, Bro. Gak ada yang salah yang salah dengan pilihan hidup lo," and "Ger, gue dukung lo, Bro!" By saying that "there is not something wrong with your life choice" and "I support you," it can be inferred that both Wicak and Banjar accept Geri just the way he is.

The last metaphor found in the conversation is when Banjar says, "Terus minum kita!" The words, "Terus minum kita!" not only can be understood as an invitation for people to drink, but also Banjar wanting to celebrate the moment when Geri finally dared to come out to reveal who he was. This also could be seen as Geri's friends' support, acceptance, as well as tolerance towards Geri's gayness.

\section{Grammar Analysis}

Grammar analysis covers several things. Grammar analysis of Negeri Van Oranje in this article covers positive and negative sentences, modes, and modality.

\section{Positive and Negative Sentences}

There are 37 positive sentences and nine negative sentences found in the conversation (Table 1).

Fairclough's (1989: 125) proposition that "negation obviously has experiential value in that it is the basic way we have of distinguishing what is not the case in reality from what is the case" suggests that when a speaker or writer tends to use a more positive sentence, they are asserting and ensuring the validity of correctness of what is being said or written. In conclusion, the fact that the positive sentences are more commonly found in the dialogue signifies that most of the utterances reflect honesty and the reality of what actually and really happens to gay people in Indonesia.

Table 1.

Positive and negative sentences in conversation between Geri and his friends when he comes out

\begin{tabular}{|l|l|}
\hline Sentence & Number of Sentence \\
\hline Positive & $2,3,4,5,7,8,9,10,11$, \\
& $12,13,14,15,18,19,20$, \\
& $21,22,23,24,25,27,28$, \\
& $31,32,33,34,35,36,37$, \\
& $38,39,42,43,44,45,46,48$ \\
\hline Negative & $1,6,16,17,26,29,30,41,42$ \\
\hline
\end{tabular}

\section{Mode Analysis}

There are three major modes, viz. declarative, grammatical question, and imperative (Fairclough, 1989: 125). From the analysis, it was found that there are 36 declarative sentences, nine grammatical sentences, and one imperative sentence (Table 2).

Table 2.

Modes in conversation between Geri and his friends when he comes out

\begin{tabular}{|c|c|c|}
\hline \multicolumn{3}{|c|}{ Modes } \\
\hline Declarative & $\begin{array}{c}\text { Grammatical } \\
\text { Questions }\end{array}$ & Imperative \\
\hline $3,4,5,6,8,9,13$, & & \\
$14,15,16,17,18$, & & \\
$19,21,23,25,27$, & $1,2,7,10,11,12$, & 26 \\
$28,29,30,31,32$, & $20,22,41$ & \\
$33,34,35,36,37$, & & \\
$38,39,40,42,43$, & & \\
$44,45,46$ & & \\
\hline
\end{tabular}

The more usage of declarative sentences in the dialogue shows that the depiction of the relationship between the speaker and the interlocutors functions more or less as that of an information provider and receiver, respectively (Fairclough, 1989). In other words, the evidence yielded from the mode analysis of the dialogue similarly reveals that the patterns the director attempted to establish between themself and the audience of the film is one of an information provider and receiver, respectively. This means that the information about gayness in the film is meant to be perceived and comprehended by the audience. 


\section{Gay Scenes Analysis}

In this analysis, representative scenes from the film were selected to shed light on all of the important scenes in the film.

Figure 2.

Scene of Geri kissing his boyfriend, which is witnessed by Lintang

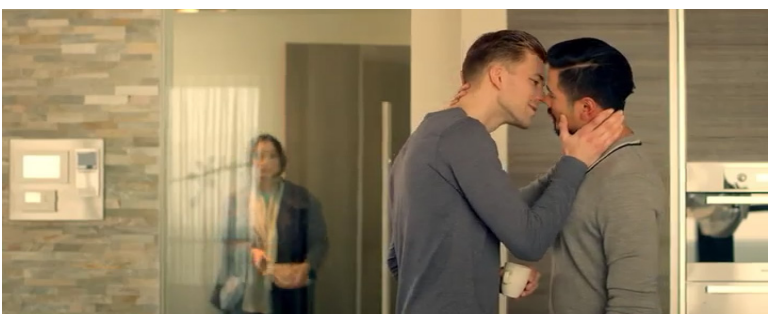

The above scene (Figure 2) shows solid evidence that Geri is gay. When a man wants to kiss a man, there are no other reasons underlying the scene than both men being romantically attracted to each other. Lintang, who stands near them, looks shocked as she realizes the man she adores is about to kiss a man. Lintang's expression can merely be seen as disappointment and surprise, but it can also signify that gayness is still considered to be something abnormal to some people. The separation between Lintang and the gay couple in the form of the glass door can be understood as the life of a gay individual in Indonesia. They are actually obvious, yet they are separated from the majority of Indonesian people.

Figure 3.

Geri's painful expression when he tells Lintang what it feels like to be a gay man

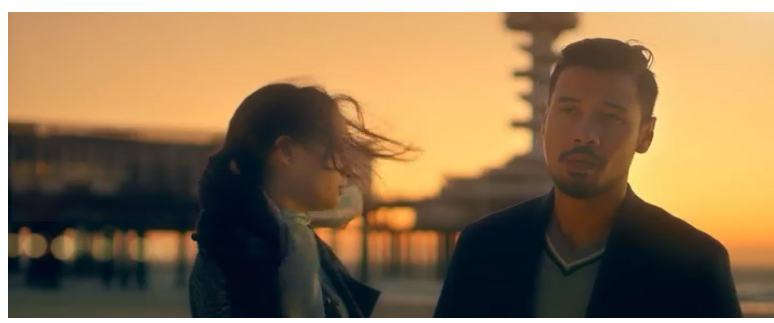

Geri shows a painful expression when he tells Lintang that he is gay (Figure 3). Although there are no sentences that literally say that Geri does not want to be gay, from his expression it can be inferred that he is suffering and that what is happening to him is something unexpected and he rejects it. The beach, as the place where Geri comes out to Lintang, can be seen as a place where people usually uncover what they feel emotionally. So, the decision to make this "coming out" scene on the beach is because the place is representative of the things that Geri will confess.

Figure 4.

Lintang hugs Geri

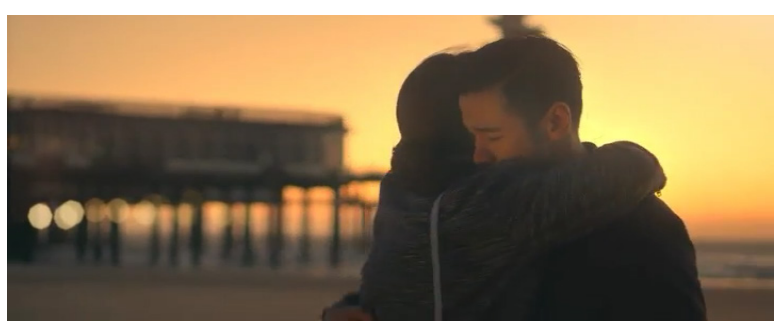

Figure 5.

Wicak shakes Geri's hand in support of his coming out

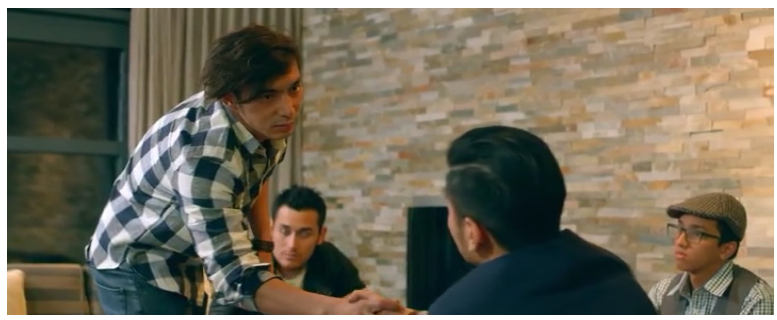

Figure 6.

Banjar shakes Geri's hand in support of his coming out

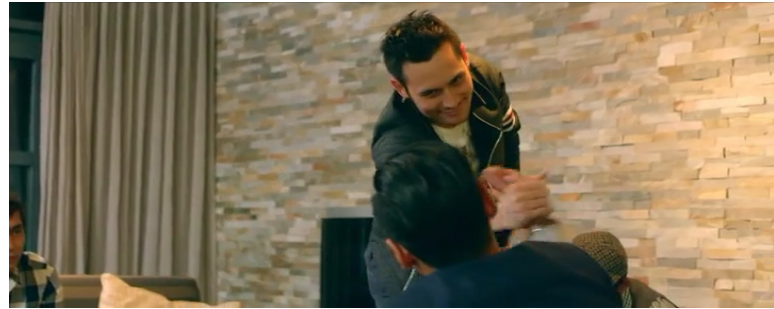

Lintang's hug and Wicak and Banjar's shaking hands are symbols of their acceptance with open arms of Geri and his particular sexual orientation (Figures 4, 5 , and 6). It can be understood that coming out is the pinnacle moment for all gay people by revealing their existence to their surroundings, making themselves visible and acknowledged. Geri's smile is a mark of his relief that his barriers have finally been loweredhe no longer needs to hide his true identity from his friends anymore (Figure 7). 
Figure 7.

Geri's happy face seeing his friends accept his gayness

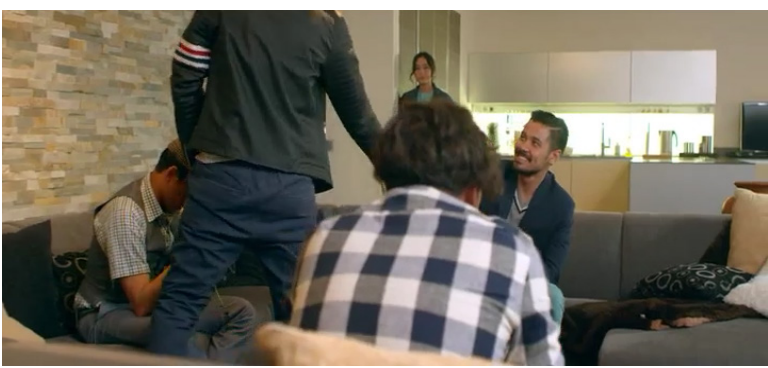

Figure 8.

Daus addresses some concerns prior to fully accepting Geri's gayness

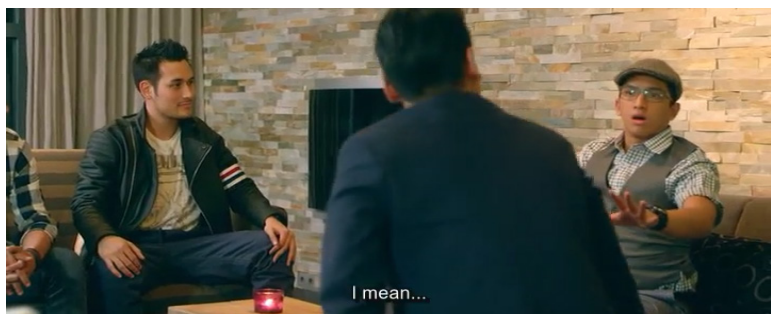

Daus's conditional acceptance of Geri's gayness, on the other hand, is a sign that not all people can accept homosexuality; they can only tolerate it. Daus will only tolerate Geri if he is capable of fulfilling his conditions.

\section{Discourse Practice Analysis}

Discourse practice analysis covers the analysis of how the text was produced and consumed (Eriyanto, 2006: 316 ). The text production analysis in this film could be done by observing both the director and the writers of the script. The script of the film was based on the novel of the same name by Wahyuningrat, Adept Widiarsa, Annisa Rijadi, and Rizki Pandu Permana. Each of them was a post-graduate student in the Netherlands. The background of the writers could be used as a base to contribute to the discourse practice analysis. Gayness has long been a common thing internationally, particularly in the Netherlands. The fact the writers resided for a long time in the Netherlands made it usual for them to talk about and promote the topic of gayness in their novel, which was subsequently adapted into a film. It allowed them to "receive" the difference, where in Indonesia the topic remains a huge and hate-filled controversy. Their acceptance of the different sexual orientation is revealed when all of Geri's friends accept his gayness.
This indirectly signifies that the writers of the script show their acceptance and support of gay people. Even though the text of Geri's gayness appears to be trivial in the context of the rest of the film - it is only presented for several minutes out of the total running time of the film - it actually contains a message that the writer of the script wanted to reveal. The short duration of the gay scenes relate to the consumption process. The fact that homosexuality is still objected to makes the director play it safe by serving those scenes over a short time frame to avoid people's resistance without losing its essence.

In addition, the decision of the film's director to select a well-known, heterosexual Indonesian actor like Chico Jericho to play the role of the gay character also makes for an interesting discussion and analysis. Logically speaking, it can be understood as the manifestation of the director's apprehension, considering gay content is very sensitive and taboo in terms of both being talked about and shown in a nationally released film like Negeri Van Oranje. It will possibly generate a problem, particularly from the audience, if the actor who plays the gay role is also one who is "allegedly" gay. Such an allegation can come from the media, such as gossip on television or in magazines. Therefore, to lessen the potential tension and resistance from the public towards the homosexual content, they used a heterosexual actor in the role. It is more or less to distract the audience's attention and establish the notion that actually the role is not that serious. In other words, casting the heterosexual actor in the role of a homosexual eases the homophobia and drives the audience to think that the gay scenes are just part of the storyline without any significant ideology and messages that the director wished to deliver to the audience about homosexuality in Indonesia.

From the audience's side (consumers of the film), the way people consume, enjoy, and discuss the film can be observed from the comments section of the YouTube channel containing the video of Negeri Van Oranje, electronic newspapers, and private blogs. From these resources, the researcher observed that most of the film's audiences did not pay much attention to the gay scenes in the movie. They tended to mind the romance narration, the beauty of its locations, and the representation of the friendship between the members of AAGABAN. This indicates two things concerning the "less attention" paid by the collective audience. Firstly, the director was skillful in wrapping the story in the film with many picturesque 
places and a captivating friendship plot, both of which made the audience more likely to neglect the gay scene. Secondly, the short amount of time devoted to the gay scenes gave the impression that the director inserted the scenes as a triviality; a petty thing to fill the running time. Therefore, even though a part of the audience was cognizant of the gay content, based on the comments found in the resources, they did not mind or feel insecure by the presence of these scenes in the film. Further proof of this statement is found in the fact that the film was successful upon its release, attracting more than 400,000 people to watch it in spite of its inclusion of gay scenes. In order words, relating the production and the consumption process of this film, it can be said that the director of the film succeeded in inserting a gay storyline, which is regarded as sensitive and taboo in Indonesia, into the nationally released film. This is an important path to mark as a success in the promotion of gayness without significant social resistance in a country where gayness is still considered queer and immoral.

\section{Sociocultural Analysis}

In situational analysis, we have to relate the parts of the film being discussed in this article to the zeitgeist of when it was made. In 2015 to 2016, gay issues were re-aroused in Indonesia. There were many discussions and debates addressing this issue (BBC News, 2017; Pleasance, 2017; Yosephine, 2016; Kwok, 2016; Westcott, 2017). Although the major theme of the film is the adventures of five Indonesian students in the Netherlands, we cannot neglect the presence of the gay scenes and when Geri comes out. If we connect it to the related situation in Indonesia, we can infer that the film's director wanted to delineate the current condition of homosexuality and show his tolerance and acceptance of gay people in Indonesia. Nevertheless, when Geri says it is difficult to be gay, that he has to pretend to be a straight man, and when Daus shows his conditional tolerance (refer to the transcript above), the director also wants to emphasize that it is very difficult to be openly gay in Indonesia.

There are some aspects we have to relate to the film in the institutional analysis. The first is the novel on which the film is based. Since it is the novel that originally portrays Geri's gayness and his coming out, these scenes also had to be presented in the film, as well. The novel is the most influencing institution, requiring the gay scenes to appear in the film. The second is Indonesians' perspectives on homosexuality.
This accounts for the small proportion the gay scenes in the film.

In the societal analysis, the researcher analyzed the influence of social aspects on the film, for example political, economic, and cultural systems. The fact that gayness is the most hate-filled and controversial issue in Indonesia, and that gay people encounter difficulties in making themselves visible or able to voice their opinions and claim their human rights, impacted the proportion of gay scenes in the film. Indeed, this proportion was based on the story in the novel. However, when it was turned into a film, the director had the authority to determine how the film would be produced. The gay scenes occupied only 6 minutes 20 seconds (1:18:10-1:24:30) out of the total duration of the film (95 minutes 39 seconds). The short duration of this content could be understood as the director wanting to make "as if" the gay scenes were merely petty complementary scenes since they contained a controversial topic. Therefore, the decision to limit their duration could be understood to indicate that the director was aware that this topic is very sensitive in Indonesia and did not want the gay scenes in the film to ruin the rating of the film in the theater. In short, to make the film still "acceptable" in Indonesia without losing its essence, which was taken from the novel, the director decided to make the scenes short.

\section{CONCLUSION}

A film does not always look as plain as it shows. Sometimes, implicitly, it brings an ideology that is supposed to be spread to its audience. Plainly, the audience will only see that the story in Negeri Van Oranje is one of the lives of five Indonesian students during their post-graduate studies in the Netherlands, involving their friendship, adventure, love, conflict, etc. The appearance of gay scenes three quarters into the film will not be regarded as an essential matter if the audience is not being critical at this point. The role of critical discourse analysis is considered pivotal in this case to deconstruct the hidden ideology so that it can be perceived clearly.

From the analysis of the gay scenes in Negeri Van Oranje, it was obtained that it is not easy to be a closeted gay or even an openly gay person in Indonesia. Aside from the fear of being rejected, hated, bullied, and marginalized, some gay people do not feel content with their sexual orientation. They actually refuse to be gay; they are confused about how to deal 
with something that they do not know when it came and became a part of their life. They object to their gayness but they are incapable of finding ways to escape it.

At some points, it can be known that homosexuality is not a matter that can be spoken about freely in public. Some of the evidence to support this notion that homosexuality is still considered taboo, based on the film analysis, is in the fact that the director chose to cast a well-known heterosexual actor to play the homosexual character in the film, as well as the limited number and duration of gay scenes in the film. This is to obscure the presence of the gay representation in the film so that the homosexual content is covered by the heterosexual persona carried by the actor. As a result, the audience will tend to think lightly of the gay content rather than problematize it.

In short, the gay scenes in Negeri Van Oranje can serve as a basis to see what happens to homosexual people in our surroundings in Indonesia, particularly in recent years; what they feel, experience, and hope to happen. Acceptance and tolerance are the two main things that they wish to obtain and how they wish to be treated. By the ability of the researcher to infer from the film these facts about how gay people live their life in Indonesia, there is solid proof that film is not just a medium for entertainment and leisure, but can also go beyond and transcend what people expect, which is to depict a sociocultural phenomenon in their surroundings.

However, the tiny scope of this research, which only covers one film, leaves several things concerning gay content in Indonesian films to be researched, such as the representation of homosexuality and gay individuals in Indonesian films across years, their iconic behaviors, iconic language styles throughout the years, etc. Future researchers are expected to analyze more Indonesian films to find and contribute something new related to Indonesian gay representation. The film, if it abides, can belong to one of the most recent crop of Indonesian films seen to have gay storylines. More profound research on this matter could make significant contributions to the attainment of a deeper understanding of gayness in Indonesia based on the perspectives planted in Indonesian films, especially in the modern age.

\section{REFERENCES}

BBC News. (2017, May 23). Indonesian men caned for gay sex in Aceh. BBC News. Retrieved from http://www.bbc.com/news/world-asia-39996224.

Bendel, J.A. (2013). A Queer Perspective: Gay Themes in The Film Interview with The Vampire. Graduate Thesis. Colorado: Colorado State University.

Bermudez, P. A. (2008). The Social Impact of "Brokeback Mountain:” A Reception Study. Graduate Thesis. Florida: University of Miami.

Eriyanto (2006). Analisis Wacana Pengantar Analisis Teks Media. Yogyakarta: LkiS.

Fairclough, N. (1989). Language and Power. New York: Longman Inc. - (1995). Critical Discourse Analysis: The Critical Study of Language. Essex: Longman.

Fauzan, U. (2013). Analisis Wacana Kritis Model Fairclough. Jurnal Pendidik, Vol. 5 (2).

Film Indonesia (2015). Data Penonton. [online article]. September 2, 2017. Available at: https:// filmindonesia.or.id/movie/viewer/2015\#.Vosf6_ 197IU

Giannetti, L. (2008). Understanding Movie. New Jersey: Pearson.

Gythfedt, T.A. (2008). That is so gay! - A textual analysis of gay male stereotypes in Six Feet Under and Queer as Folk (with a queer theoretical perspective). Unpublished Graduate Thesis. Oslo: University of Oslo.

Kwok, Y. (2016, February 23). LGBT Rights in Indonesia Are Coming Under 'Unprecedented Attack'. Time. Retrived from http://time.com/4447819/ indonesia-lgbt-islam-muslim-gay-bi-transgender.

Maimunah (2014). Understanding Queer Theory In Indonesian Popular Culture: Problems and Possibilities. Jurnal Lakon, Vol. 1 (3).

Muthmainah, Y. (2016). LGBT Human Right in Indonesian Police. Indonesian Feminist Journal, Vol. 4 (1).

Nugroho, S.C et al. (2010). Pengambilan Keputusan Menjadi Homoseksual Pada Laki-Laki Usia Dewasa Awal. Semarang: Diponegoro University.

Pew Research Center (2013). The Global Divide on Homosexuality: Greater Acceptance in More Secular and Affluent Countries. [online article]. August 14 ${ }^{\text {th }}$, 2017. Available at: http://www. pewglobal.org/2013/06/04/the-global-divideon-homosexuality/.

Pleasance, C. (2017, May 23). Two gay men are each caned 85 times in Indonesia's only sharia law province after vigilante group raided their home and handed them over to the authorities. Retrieved from http://www.dailymail.co.uk/ 
news/article-4533004/Gay-men-caned-85-timesSharia-lawsIndonesia.html.

Rahikainen, E. (2014). "You, my friend, are a gaycist" Gay representations and heteronormativity on the comedy series Happy Endings. Undergraduate Thesis. Jyväskylä: University of Jyväskylä.

Riantrisnanto, R. (2016, January 26). 10 Film Indonesia Terlaris 2015 Beserta Pendapatannya. Liputan6. com. Retrieved from http://liputan6.com/shiwbiz/ $\mathrm{read} / 2421017 / 10$-film-indonesia-terlaris-2015beserta-pendapatannya.

Setiawan, I. Yang Muda Yang Bertingkah: Konsumsi resistensi, dan kreativitas kaum muda dalam budaya pop. MataTimoer Institute. 17 August 2016. Available at: http://matatimoer. or.id/2016/08/17/yang-muda-yang-bertingkahkonsumsi-resistensi-dan-kreativitas-kaum-mudadalam-budaya-pop/.

Sinthiani (2011). Analisis Semiotic Film 3 Dunia Dua Hati Satu Cinta. Undergraduate Thesis. Jakarta: Islam State University of Syarif Hidayatullah.

Spargo, T. (2000). Foucault and Queer Theory. London: Cox \& Wyman Ltd.

Sugiarto, T. (2013). Analisis Wacana Gambaran Kehidupan homoseksualitas dalam Novel
"Pria Terakhir" Karya Gusnaldi. eJournal Ilmu Komunikasi, Vol. 1 (4), pp. 1-10.

UNDP, USAID. Being LGBT in Asia: Indonesia Country Report. Bangkok: UNDP.

van Dijk (1995). Aims of Critical Discourse Analysis. Japanese Discourse, Vol. 1, pp. 1-27.

Wedhanti, P. H and Fridari, I. G. A. (2014). Dinamika Kesetiaan Pada Kaum Gay. Jurnal Psikologi Udayana, Vol. 1 (2), pp. 363-371.

Westcott, B. (2017, June 1). Never seen anything like this': Inside Indonesia's LGBT crackdown. $C N N$. Retrieved from http://edition.cnn. com/2017/05/31/asia/indonesia-lgbt-rights/index. html

Yosephine, L. (2016, May 16). A Portrait of a Gay Indonesian. The Jakarta Post. Retrieved from http://www.thejakartapost.com/ longform/2016/05/16/a-portrait-of-a-gayindonesian.html.

Zhang, X. (2014). Portrayals of gay characters in Chinese films: A longitudinal look. Graduate thesis. Iowa: Iowa State University. 